\title{
CORRECTION: A mouse model of osteonecrotic femoral head induced by methylprednisolone and lipopolysaccharide
}

\author{
Ha Thi -Ngan Le, Lan Thi Phi, Thuy Thi-Thanh Dao, Ngoc Kim Phan, \\ Phuc Van Pham, Ngoc Bich Vu*
}

Laboratory of Research and Application Stem Cell, University of Sciences, Vietnam National University, Ho Chi Minh City, Vietnam

The title of the article "A mouse model of osteonecrotic femoral head *For correspondence: vbngoc@hcmus.edu.vn Competing interests: The authors declare that no competing interests exist.

Received: 15 March 2017 Accepted: 20 April 2017 Published: 27 April 2017

Copyright The Author(s) 2017. This article is published with open access by BioMedPress (BMP).

This article is distributed under the terms of the Creative Commons Attribution License (CC-BY 4.0) which permits any use, distribution, and reproduction in any medium, provided the original author(s) and the source are credited. induced by methylprednisolone and liposaccharide" published in 25 March 2016, in 2016 at Vol 3, Issue 3, from pages: 548-556 (DOI: 10.7603/ s40730-016-0012-x)

should be read as:

"A mouse model of osteonecrotic femoral head induced by methylprednisolone and lipopolysaccharide". 